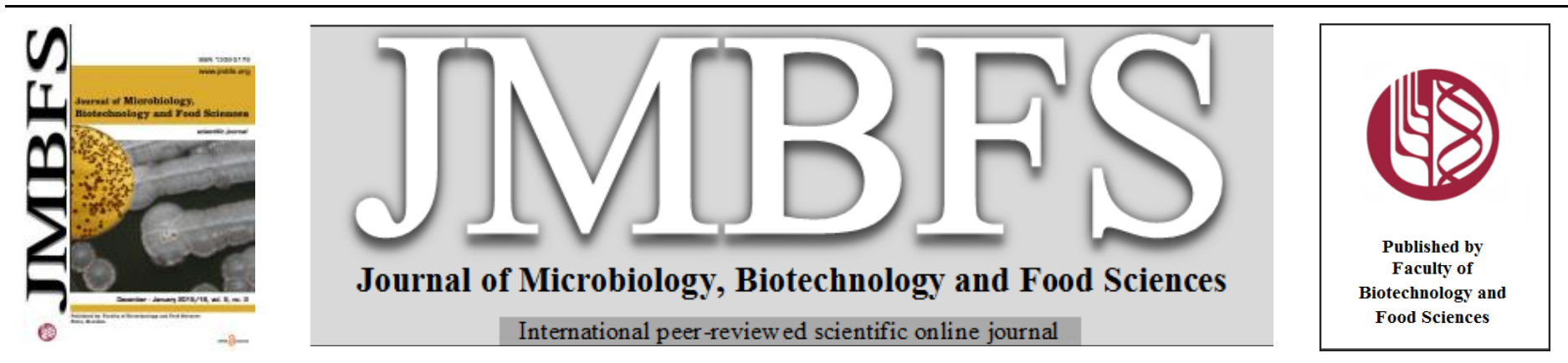

\title{
IN VITRO ANTIMICROBIAL ACTIVITY AND PHYTOCHEMICAL STUDIES OF TERMINALIA CHEBULA AGAINST THE MICROBES ISOLATED FROM FRUIT JUICES
}

\author{
Romika Dhiman, Neeraj Kumar Aggarwal", K.R. Aneja, Manpreet Kaur, Vikas kumar
}

Address(es): Assistant Professor, Neeraj Kumar Aggarwal,

Department of Microbiology, Kurukshetra University Kurukshetra, India, 136119.

*Corresponding author: neerajkuk26@ rediffmail.com

doi: 10.15414/jmbfs.2015/16.5.3.243-247

\section{ARTICLE INFO}

Received 18. 5. 2015

Revised 11. 9. 2015

Accepted 27. 9. 2015

Published 1. 12. 2015

Regular article

open $\partial_{\text {Access }}$

\begin{abstract}
The present work has been conducted to evaluate the antimicrobial activity of Terminalia chebula against microorganisms associated with juices. Methanol, ethanol, acetone, and aqueous ( hot and cold) extracts from fruits of $T$. chebula were tested for their antimicrobial activity through agar well diffusion method and minimum inhibitory concentration (MIC)/minimum bactericidal concentration (MBC) values were determined through the macrodilution broth method against Bacillus cereus, Serratia sp. and Rhodotorula mucilaginosa. Their total phenolic content and total tannin content were also evaluated. Organic and cold aqueous extracts displayed activity against all three tested microbes. There were highly positive relationship between antimicrobial activities and phenolic and tannin content of the tested extracts against each microorganism. Methanolic extract was found to be best against all tested microbes with lowest MIC of 0.78 $\mathrm{mg} / \mathrm{ml}$ and MBC of $1.56 \mathrm{mg} / \mathrm{ml}$ and showed better antimicrobial activity than sodium benzoate. Therefore, methanolic extract of $T$. chebula has a biopreservative potential in fruit juices.
\end{abstract}

\section{INTRODUCTION}

Consumption of fresh fruit juices has increased in the last decades owing to antioxidants, vitamins and minerals that these juices provide to the people and help in reducing the risk of heart diseases, cancer and diabetes (MosquedaMelgar et al., 2012). These are considered as safe foods due to their low $\mathrm{pH}$ caused by naturally occurring organic acids which may prevent the growth of microbes (Mosqueda-Melgar et al., 2008), but allow the growth of certain acid tolerant bacteria, yeasts and moulds. Spoilage of fruit juices is characterized by formation of $\mathrm{CO} 2$, alcohol, cloud loss and formation of fermented flavor attributed to pectin esterases (ICMSF 2005; Lawlor et al., 2009; Tribst $\boldsymbol{e t}$ al., 2009). Fruit juices spoilage bacteria include acid tolerant bacteria such as acetic acid bacteria, lactic acid bacteria, Clostridium, Bacillus, members of Enterobacteriaceae family (Klebsiella sp., Citrobacter sp. and Serratia sp.) and some heat resistant bacteria such as Alicyclobacillus acidoterrestris and Propionibacterium cyclohexinicum. Among yeasts Pichia, Candida, Saccharomyces and Rhodotorula are commonly encountered genera responsible for spoilage of juices (Lawlor et al., 2009; Raybaudi-massilia et al., 2009 Bevilacqua et al., 2011).

Chemical preservatives such as sodium benzoate are widely used in foods and beverages, that naturally are in $\mathrm{pH}$ range below 4.5 , in several countries and enjoy GRAS status up to a maximum permitted level of $0.1 \%$ in USA and 0.15 $0.25 \%$ in Many countries (Chipley, 2005).

Consumer demand for minimally processed food products, with less use of chemical preservatives and at the same time without compromising food safety has increased interest in the use of natural antimicrobial compounds as biopreservatives in fruit juices (Lawlor et al., 2009; Negi, 2012). Natural antimicrobials such as organic acids, essential oils, plant extracts, and bacteriocins could be good alternative to ensure food safety (Raybaudi- Massilia et al., 2009 ; Burt, 2004; Tiwari et al., 2009). The use of plant extracts, either as pure compounds or as standardized extracts, provides unlimited opportunities for control of microbial growth attributed to their chemical diversity.

Terminalia chebula is important medicinal plant widely distributed throughout India, Burma, Pakistan, Nepal, south-west China and Srilanka. It is commonly known as black myroblans and harad, belong to Combretaceae family. In Tibet, the fruit of Terminalia chebula is called the "king of medicine". It is medium size deciduous tree attaining a height of $25-30 \mathrm{~m}$; with spreading branches and a broad roundish crown (Sharma et al., 2012; Rathinamoorthy and Thilagavathi, 2014).
The fruit of the tree possesses diverse health benefits and has been used as traditional medicine for household remedy against asthma, sore throat, vomiting, hiccough, diarrhea, bleeding piles, gout, and heart and bladder disease. It is good to increase appetite, digestive aid, liver stimulant, stomachic, gastrointestinal, and mild laxative (Bag et al., 2013). In Terminalia chebula, 33\% of the total phytoconstituents are hydrolysable tannins and are responsible for pharmacological activity. Many researchers have reported 14 components of hydrolysable tannins like gallic acid, chebulagic acid, punicalagin, chebulanin, corilagin, neochebulinic acid, ellagic acid, chebulinic acid, 1,2,3,4,6-penta-Ogalloyl- $\beta$-D-glucose, 1,6-di-o-galloyl-D-glucose, casuarinin, 3,4,6-tri-o-glloyl-Dglucose, terchebulin (Juang et al., 2004; Sharma et al., 2012; Bag et al., 2013)

The nature of the extracting solvent is most important factor in the extraction of antimicrobial compounds from plants. The most suitable solvents for plant extraction are polar solvents such as water, methanol, ethanol and acetone (Chang and Lin, 2012).

The main aim of the present study was to determine the in vitro antimicrobial activity of $T$. chebula fruits against the isolated microbes from fruit juices and to compare the effect of different solvents in the extraction method for antimicrobial activity. Quantitative phytochemical analysis of phenol and tannin content of different solvent extracts of $T$. chebula fruits was performed to establish a relationship between microbial inhibition and phytochemical constituents (Phenol and tannin).

\section{MATERIALS AND METHODS}

\section{Plant collection}

The fruits of T. chebula were obtained from the local market in Yamunanagar. The taxonomic identity of the plant was confirmed by Dr. B.D. Vashishta, plant taxonomist, Chairman of Botany Department, Kurukshetra University, Kurukshetra.

\section{Extraction of plant material}

The samples were carefully washed under running tap water followed by sterile distilled water and air dried at room temperature $\left(35-40^{\circ} \mathrm{C}\right)$ for $4-5 \mathrm{~d}$, homogenized to a fine powder using a sterilized mixer grinder and stored in air tight bottles. Four different solvents, namely ethanol, methanol, acetone and aqueous (hot and cold), were used for extraction. A $10 \mathrm{~g}$ of fruits were separately 
soaked in conical flasks each containing $100 \mathrm{ml}$ of acetone, ethanol, methano $(95 \%)$ and sterile distilled water.

Also, an equal amount (i.e., $10 \mathrm{~g}$ ) of homogenized fruits was immersed separately in $100 \mathrm{ml}$ of hot sterile distilled water in conical flasks and allowed to stand for 30 min in a water bath $\left(\right.$ at $100^{\circ} \mathrm{C}$ ) with occasional shaking, followed by keeping al the flasks on rotary shaker at $200 \mathrm{rpm}$ for $24 \mathrm{~h}$. Each preparation was filtered through a sterilized Whatman No. 1 filter paper and finally concentrated to dryness under vacuum at $40^{\circ} \mathrm{C}$ using a rota evaporator. The dried extract thus obtained was sterilized by overnight ultra violet-irradiation, checked for sterility on nutrient agar plates and stored at $4^{0} \mathrm{C}$ in labelled sterile bottles until further use (Sharma et al., 2012)

\section{Test microorganism}

Two bacteria, namely Serratia sp.(KC67407*), Bacillus cereus KRC1 (KC67408) and one yeast, Rhodotorula mucilaginosa (KC67409) were isolated from fruit juices. Bacterial strains were identified on the basis of gram staining, biochemical and molecular characteristics (16S rRNA sequencing) (Lawlor et al, 2009). Yeast was identified on the basis of staining, morphological, cultural characteristics and molecular characteristics (28S rRNA sequencing). The bacterial isolates were subcultured on nutrient agar and $R$. mucilaginosa on potato dextrose agar and incubated aerobically at $37^{\circ} \mathrm{C}$ and $25^{\circ} \mathrm{C}$ respectively. The media were procured from Hi Media Laboratory Pvt. Ltd., Bombay, India (*Nucleotide sequence of all microorganisms has been submitted to GenBank database which provided the GenBank accession number, KC67407- KC67409).

\section{Screening for antimicrobial activity}

The acetone, methanol, ethanol, hot and cold aqueous solvent extracts of $T$ chebula fruits were used for evaluation of antimicrobial activity by the agar well diffusion method. In this method, a pure isolate of bacteria and yeast was grown on NA and PDA plates and incubated at $37^{\circ} \mathrm{C}$ and $25^{\circ} \mathrm{C}$ for $24 \mathrm{~h}$ and $72 \mathrm{~h}$ respectively. One plate of each microorganism was taken and colonies were transferred into normal saline $(0.85 \%)$ under aseptic conditions. Density of each microbial suspension was adjusted to be equal to that of $10^{6} \mathrm{cfu} / \mathrm{mL}$ (standardized by $0.5 \mathrm{McFarland}$ standard) and used as the inoculum for performing an agar well diffusion assay. One hundred microliter $(100 \mu \mathrm{L})$ of the inoculum of each tes organism was spread onto the agar plates so as to achieve a confluent growth The agar plates were allowed to dry and $8 \mathrm{~mm}$ wells were made with a sterile borer in the inoculated agar plates. The lower portion of each well was sealed with molten agar medium. The dried extract samples of $T$. chebula fruits was dissolved in dimethylsulphoxide (DMSO) to the final concentration of 100 $\mathrm{mg} / \mathrm{mL}$ for the bioassay analysis. A $100 \mu \mathrm{L}$ volume of each extract was propelled directly into the wells (in triplicate) of the inoculated agar plates for each test organism. The plates were allowed to stand for $1 \mathrm{~h}$ at room temperature $\left(40^{\circ} \mathrm{C}\right)$ for diffusion of the extract into agar and incubated at $37^{\circ} \mathrm{C}$ and $25^{\circ} \mathrm{C}$ for $24 \mathrm{~h}$ and $72 \mathrm{~h}$ respectively. Sodium benzoate $(100 \mathrm{mg} / \mathrm{ml})$ was used as positive reference standards to determine the sensitivity of each microbial species tested. Sterile DMSO served as the negative control. The antimicrobial activity, indicated by an inhibition zone surrounding the well containing the extract, was recorded if the zone was greater than $8 \mathrm{~mm}$. The experiments were performed in triplicate and the mean values of the diameter of inhibition zones \pm standard deviations were calculated (Shan et al., 2007; Aneja et al., 2011).

\section{Determination of minimum inhibitory concentration}

Minimum inhibitory concentration (MIC) for each test organism was determined by the macrodilution broth method. A twofold serial dilution of each extract was prepared by first reconstituting the dried extract $(100 \mathrm{mg} / \mathrm{mL})$ in DMSO followed by dilution in Mueller-Hinton broth (bacteria) and potato dextrose broth (yeast) to achieve a decreasing concentration range of $50 \mathrm{mg} / \mathrm{mL}$ to $0.39 \mathrm{mg} / \mathrm{mL}$. Each dilution was seeded with $100 \mu \mathrm{L}$ of the standardized microbial inoculum $\left(1.5 \times 10^{6} \mathrm{cfu} / \mathrm{mL}\right)$. The inoculated culture tubes of bacteria were incubated at $37^{\circ} \mathrm{C}$ for $24 \mathrm{~h}$ and yeast at $25^{\circ} \mathrm{C}$ for $72 \mathrm{~h}$. A set of tubes containing only broth was kept as control. Afterwards, incubation tubes were examined for changes in turbidity as an indicator of growth. The lowest concentration that did not permit any visible growth was considered as MIC (Das et al., 2010).

\section{Determination of minimum bactericidal concentration}

Minimum bactericidal concentration (MBC) is the lowest concentration of antimicrobial agent that will not allow the growth of an organism afte subculturing on antibiotic free media. MBC was determined by subculturing the preparations that did not show any bacterial growth in the MIC determination. A $100 \mu \mathrm{L}$ aliquot from the selected tube (showing MIC) was spread over the MHA plate and incubated at $37^{\circ} \mathrm{C}$ for 24 hours and examined for bacterial growth. The $\mathrm{MBC}$, the lowest concentration of the plant extract giving $99.9 \%$ reduction of the bacterial growth of various plants parts against the bacterial pathogens, was recorded (Ncube et al., 2008; Sharma et al., 2012).

\section{Determination of minimum fungicidal concentration}

A loopful of culture from each set of tubes that did not show any visible growth of the yeast in MIC determination was subcultured on to fresh plates of PDA and incubated at $25^{\circ} \mathrm{C}$ for 72 hours. Minimum fungicidal concentration for each plant extracts against the tested yeast was recorded as the lowest concentration that did not yield any fungal growth on the solid medium (Aneja et al., 2011).

\section{Determination of total phenolic content}

Total phenolic content was estimated using the Folin- Ciocalteu colorimetric method. The appropriate dilutions of the extract sample $(0.2 \mathrm{ml})$ were oxidized 4 min with $1 \mathrm{ml}$ of $0.5 \mathrm{M}$ Folin-Ciocalteu reagents and then the reaction was neutralized with saturated sodium carbonate $(75 \mathrm{~g} / 1) 1 \mathrm{~mL}$. The absorbance of the resulting blue color was measured at $760 \mathrm{~nm}$ with a spectrophotometer after incubation for $30 \mathrm{~min}$. at room temperature. Quantification was done based on a standard curve of gallic acid. Results were expressed as milligram of expressed in milligram gallic acid equivalents (mg gallic acid/g extract). All tests were performed in triplicate (Shan et al., 2007).

\section{Determination of total tannin content}

Analysis of total tannin was determined by titrimetric method. Zinc ion reacts with tannin compounds in alkali solution, to form complexes. Residual zinc ion is then titrated with EDTA, and zinc complexed tannin is determined from EDTA consumption and total zinc content. The acetone, methanol, ethanol, hot and cold aqueous extracts (1 mg each) were each placed into glass vials and dissolved with $1 \mathrm{~mL}$ of deionized water. The vials were warmed in a water bath for $5 \mathrm{~min}$ at $35 \pm$ $2 \circ \mathrm{C}$. ZnAc $(1 \mathrm{M}, 0.4 \mathrm{~mL})$ and $\mathrm{NH}_{3}(0.28 \mathrm{~mL})$ were mixed together, and the warmed $1-\mathrm{mL}$ extract solutions were added. The solutions were replaced in the water bath for $30 \mathrm{~min}$ at $35 \pm 2{ }^{\circ} \mathrm{C}$. Deionized water $(8.92 \mathrm{~mL})$ was added to make the final volume up to $10.6 \mathrm{~mL}$. After careful filtering, sample solutions were obtained. The solutions $(0.8 \mathrm{~mL})$ were further diluted with $5.2 \mathrm{~mL}$ of deionized water, and $0.5 \mathrm{~mL}$ of $\mathrm{NH} 3-\mathrm{NH} 4 \mathrm{Cl}$ buffer $(\mathrm{pH} 10)$ was added. Finally, the mixture was titrated with $0.05 \mathrm{M}$ EDTA. The blank was detected without addition of the extract. The total tannin content $(\% / \mathrm{mg}$ extract) of each extract was calculated as follows: $\left\{\left[0.1556 \times\left(\mathrm{V}_{\text {blank }}-\mathrm{V}_{\text {extract }}\right)\right] / \mathrm{W}_{\text {extract }}\right\} \times 100 \%$. $\mathrm{V}_{\text {blank }}$ and $V_{\text {extract }}$ represent the EDTA titration volumes $(\mathrm{mL})$ recorded for the respectiveblank and extract solutions. W represents the weight (mg) of each extract (Shan et al., 2007).

\section{Statistical analysis}

The experimental results were repeated thrice in triplicate each time and expressed as mean \pm SD and results were statistically evaluated using Dennett's $T$-test. $P$ value less than 0.05 was considered significant.

\section{RESULTS}

\section{Extraction yield}

A perusal of data in table 3 represent the yield, total phenolic and tannin content of the four extracts. The yield of the four extracts varied from $13.6 \%$ to $19.6 \%$.

\section{Total phenolic content}

Total phenolic content was determined for the extracts of $T$. chebula which show the best antimicrobial activity from a linear gallic acid standard curve. The tota phenolic content of four extracts varied from $416.3 \mathrm{mg}$ to $720 \mathrm{mg}$ gallic acid/g extract. The greatest concentration of phenolic content was observed in methanolic extract of $T$. chebula fruits.

\section{Tannin content}

The total tannin content of the four active extracts varied from 15.3 .6 to $29.3 \%$ This result suggests that the methanolic extract provided the greatest concentration of tannin content of the four extracts.

\section{Effect of solvent on antimicrobial activity}

The antimicrobial activity of $T$. chebula fruits extracts differed in various organic (methanol, ethanol, acetone) and aqueous (hot and cold) extracts. Positive contro showed significantly sized inhibition zone against the tested bacteria (ranging between 16.8-21.7) and the yeast (with zone of inhibition 14.7) and negative control did not produce inhibitory effect against all tested microbes. A perusal of the data in table 2 reveals that all organic and cold aqueous solvents of fruit extracts possessed antibacterial and antiyeast activity against tested microbes. Hot aqueous extracts of fruits of $T$. chebula lacked antimicrobial activity against Serratia sp. and $R$. mucilaginosa. Methanolic extract of fruits was found most effective against $B$. cereus $(25.6 \mathrm{~mm})$ followed by Serratia $\mathrm{sp} .(23.3 \mathrm{~mm})$. The 
antimicrobial activity of organic extracts of fruits was found better than sodium benzoate.

The MIC values ranged between $0.78 \mathrm{mg} / \mathrm{ml}$ and $50 \mathrm{mg} / \mathrm{ml}$ for the different fruit juice associated microorganisms. MBC values ranged between $1.56 \mathrm{mg} / \mathrm{ml}$ and $50 \mathrm{mg} / \mathrm{ml}$. Among all the tested fruits solvent extracts, methanolic extract of fruits was the best solvent where the lowest MIC of $0.78 \mathrm{mg} / \mathrm{ml}$ and MBC of 1.56 $\mathrm{mg} / \mathrm{ml}$ was observed against $B$. cereus that followed by MIC value of $6.25 \mathrm{mg} / \mathrm{m}$ against $R$. mucilaginosa and MIC was $12.5 \mathrm{mg} / \mathrm{ml}$ for $S$. marcescens (Table 3) All the obtained results were statistically significant as they showed $(\mathrm{P}<0.05)$ compared with control (Table 2).

Relationship between antimicrobial activity, total phenolic content and total tannin content

The correlation between antimicrobial activity and phenolic content are shown in figure 1 . The $\mathrm{R}^{2}$ values were between 0.99 and 0.88 and decreased in the following order Serratia $>$ B. cereus $>$ R. mucilaginosa.

The relationship between antimicrobial activity and total tannin content was also calculated (Fig 2). The $\mathrm{R}^{2}$ values were between 0.70 and 0.95 and decreased in the following order B. cereus $>$ Serratia $>$ R. mucilaginosa.

Table 1 Extraction yield, total phenolic content and total tannin content of the four extracts of Terminalia chebula

\begin{tabular}{|c|c|c|c|}
\hline Extract & Extraction yield $^{\mathrm{a}}$ & $\begin{array}{c}\text { Total phenolic } \\
\text { content }^{\mathrm{b}}\end{array}$ & $\begin{array}{c}\text { Total tannin } \\
\text { content }^{\mathrm{c}}\end{array}$ \\
\hline Acetone & $17.2 \pm 1.8$ & $556.6 \pm 7.6$ & $21.0 \pm 2.64$ \\
\hline Methanol & $19.6 \pm 2.6$ & $720.0 \pm 9.5$ & $29.3 \pm 2.5$ \\
\hline Ethanol & $15.4 \pm 2.4$ & $600.3 \pm 8.3$ & $26.6 \pm 3.2$ \\
\hline Cold aq & $13.6 \pm 1.2$ & $416.3 \pm 5.2$ & $15.3 \pm 3.1$ \\
\hline
\end{tabular}

Table 2 Antimicrobial activity of Terminalia chebula fruits extracts against juice associated bacteria and yeast by agar well diffusion method

\begin{tabular}{lccc}
\hline Solvent extracts $\mathrm{mg} / \mathrm{ml}$ & $\mathrm{Bc}$ & $\mathrm{Sm}$ & $\mathrm{Rm}$ \\
\hline Acetone & $19.3^{\mathrm{a}} \pm 0.57^{\mathrm{b}}$ & $18.6 \pm 1.15$ & $17.6 \pm 0.57$ \\
Methanol & $25.6 \pm 0.57$ & $23.3 \pm 0.57$ & $19.3 \pm 0.57$ \\
Ethanol & $22.6 \pm 0.57$ & $19.3 \pm 0.57$ & $16.6 \pm 0.57$ \\
Cold aq & $17.3 \pm 0.57$ & $14.6 \pm 1.15$ & $14.3 \pm 0.57$ \\
Hot aq & $14.3 \pm 0.57$ & - & - \\
Control & $20 \pm 1$ & $15.6 \pm 0.57$ & $14.6 \pm 0.57$ \\
Dmso & - & - & -
\end{tabular}

$\mathrm{Bc}=$ Bacillus cereus, $\mathrm{Sm}=$ Serratia marcescens, $\mathrm{Rm}=$ Rhodotorula mucilaginos,$(-)=\mathrm{no}$ activity, ${ }^{\text {a }}$ Values, including diameter of the well $(8 \mathrm{~mm})$, are means of three replicates, ${ }^{\mathrm{b}} \pm$ Standard deviation, data were analyzed by one way analysis of variance followed by Dunnett"s test.

Table 3 Minimum inhibitory concentration, minimum bactericidal concentration and minimum fungicidal concentration of Terminalia chebula leaves and fruits extracts against juice associated bacteria and yeast

\begin{tabular}{lcccc} 
Solvent extracts & $\mathrm{mg} / \mathrm{ml}$ & $\mathrm{Bc}$ & $\mathrm{Sm}$ & $\mathrm{Rm}$ \\
\hline \multirow{2}{*}{ Acetone } & & & & \\
& MIC & 1.56 & 6.25 & 25 \\
\multirow{2}{*}{ Ethanol } & MBC & 3.12 & 12.5 & 50 \\
\multirow{2}{*}{ Methanol } & MIC & 1.56 & 25 & 12.5 \\
& MBC & 3.12 & 50 & 25 \\
\multirow{2}{*}{ Hot aqueous } & MIC & 0.78 & 12.5 & 6.25 \\
\multirow{2}{*}{ Cold aqueous } & MBC & 1.56 & 25 & 12.5 \\
& MIC & 50 & $\mathrm{Nt}$ & $\mathrm{Nt}$ \\
& MBC & $>50$ & $\mathrm{Nt}$ & $\mathrm{Nt}$ \\
& MIC & 50 & 25 & 25 \\
\hline
\end{tabular}

$\mathrm{Bc}=$ Bacillus cereus, $\mathrm{Sm}=$ Serratia marcescens, $\mathrm{Rm}=$ Rhodotorula mucilaginosa, $\mathrm{MIC}=$ Minimum inhibitory concentration; $\mathrm{MBC}=$ minimum bactericidal concentration; $\mathrm{MFC}=$ minimum fungicidal concentration.

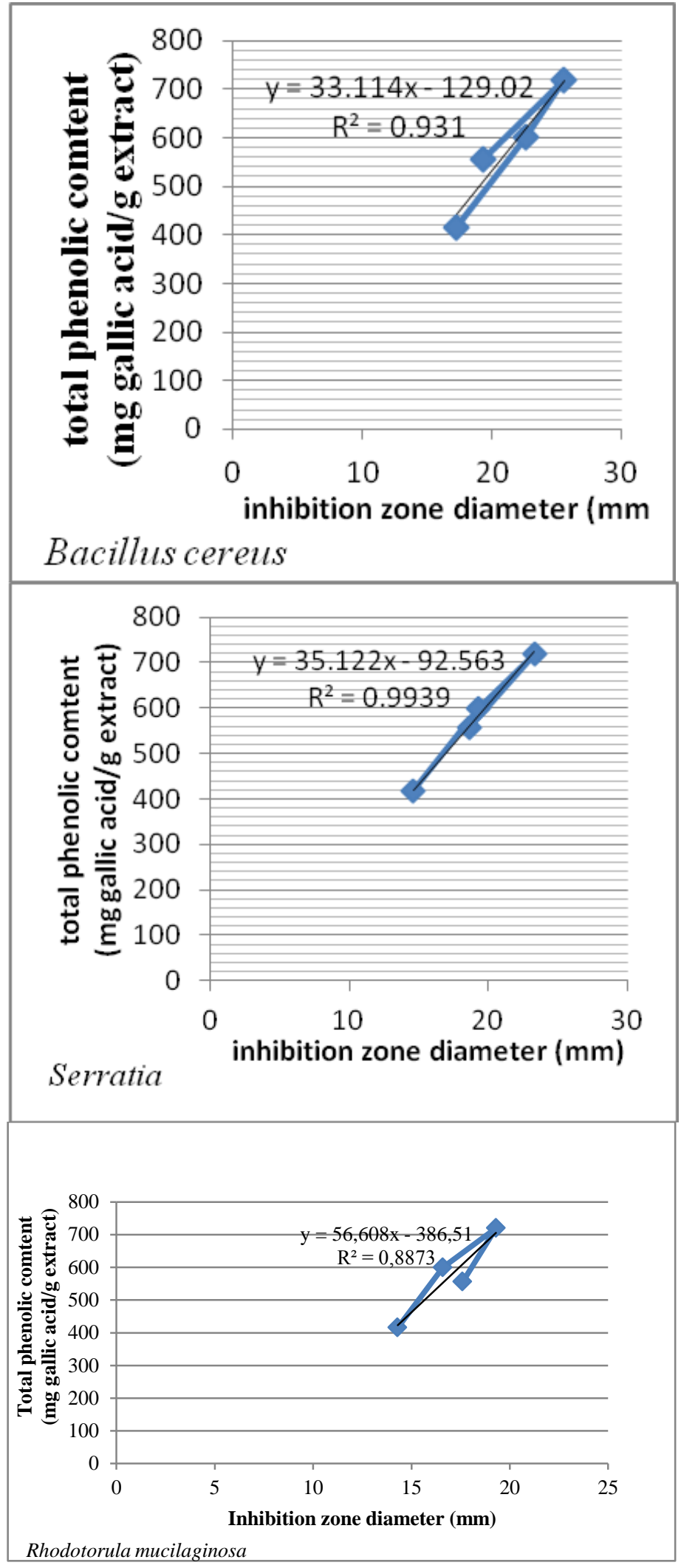

Figure 1 Relationship between inhibition zone diameter ( $\mathrm{mm}$ ) and total phenolic content (mg gallic acid equivalents/ $\mathrm{g}$ extract) of 4 solvent extracts from $T$. chebula fruits for microbes associated with juices 

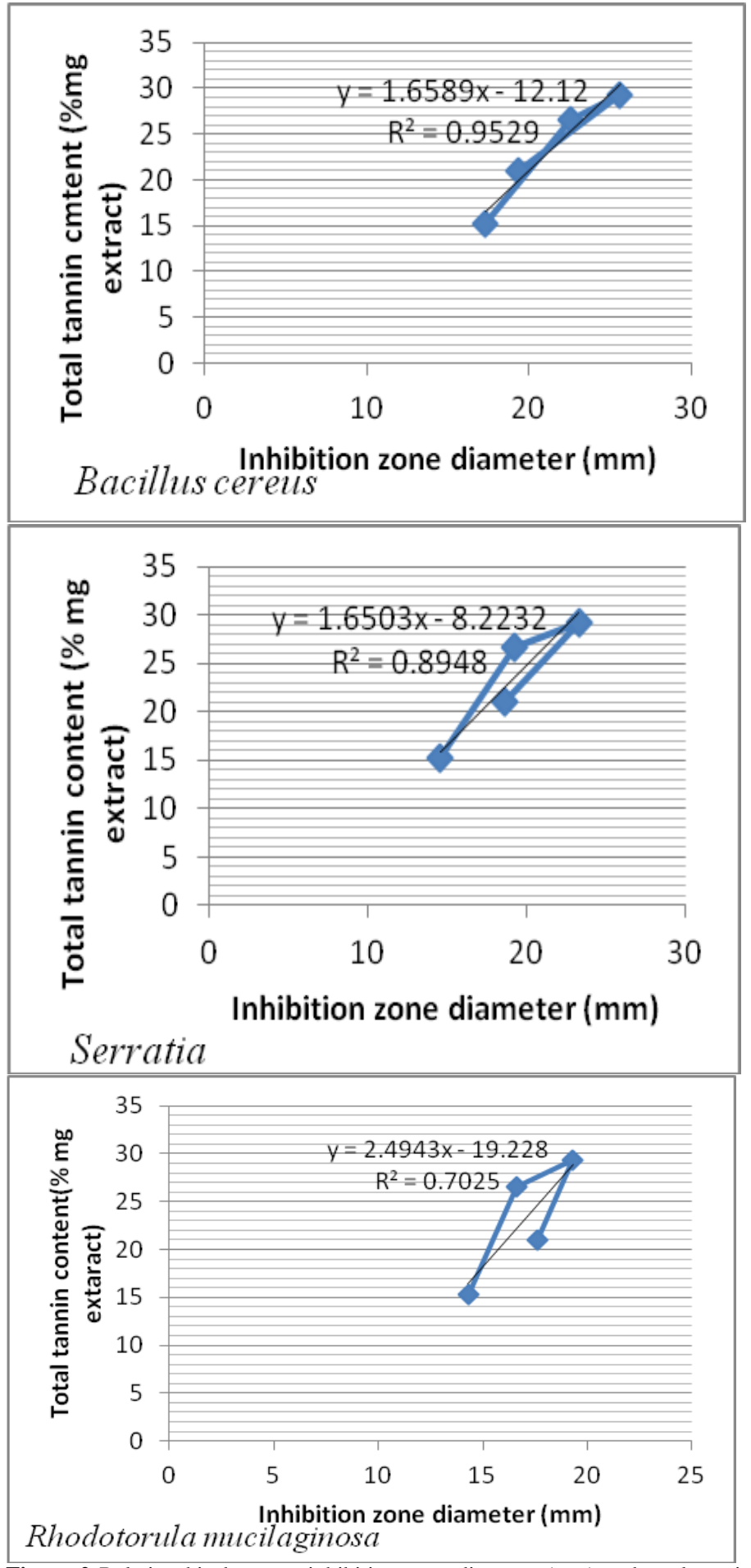

Figure 2 Relationship between inhibition zone diameter $(\mathrm{mm})$ and total tannin content (\% mg extract) of 4 solvent extracts from $T$. chebula fruits for microbes associated with juices

\section{DISCUSSION}

The use of dietary herb and spices as food additives in foods to improve the sensory characteristics of food but also increase the shelf life by reducing or eliminating survival of pathogenic bacteria (Tajkarimi et al., 2010). Numerous studies have been done in-vitro to evaluate the antimicrobial activity of plan extracts; very few studies are available for food products owing to the use of crude extracts in most studies (Negi, 2012). T. chebula is an important medicinal plant always listed at the top of the list of 'Ayurvedic Materia Medica' attributed to its extraordinary power of healing and traditionally used in the treatment of various ailments for human beings (Bag et al., 2012). Therefore, in the present study, different organic (ethanol, methanol, acetone) and aqueous (hot and cold) fruit extracts of this plant were evaluated for their antibacterial and antifungal potential for the first time against the microbes associated with fruit juices. In our observations, the organic fruit extracts of $T$. chebula were found to be the most active in inhibiting the growth of all the tested microbes compared to aqueous extracts. Our investigation was confirmed by earlier observations on an alcoholic extract that exhibited greater activity than the aqueous extracts against bacteria (Ahmad et al., 1998; Sharma et al., 2012; Bag et al., 2012). Several other works has also been reported about the antibacterial activity of $T$. chebula fruit extracts against E. coli, Helicobacter pylori, Staphylococcus aureus, Salmonella typhi, S. epidermidis, Bacillus subtilis, Proteus vulgaris and Pseudomonas aeruginosa (Chattopadhyay and Bhattacharyya, 2007; Kannan et al., 2009; Sharma et al., 2012). T. chebula fruit extracts in organic solvents also exhibit antifungal activity against $R$. mucilaginosa in present study and same observations were confirmed by several workers (Dutta et al., 1998; Mehmood et al., 1999; Bonjar, 2004).

In the present study, among the three microorganisms tested, B. cereus was the most sensitive to the five different extracts of $T$. chebula fruits. The highest sensitivity of $B$. cereus may be due to its cell wall structure and outer membrane (Shan et al., 2007; Negi, 2012).

A majority of the described antimicrobial effects of $T$. chebula extracts have been attributed to their secondary metabolites, notably tannins, gallic acid, chebulic acid, chebulagic acid, corilagin, mannitol and other compounds (Bag et al., 2012, 2013). Phenols and tannins are the most common active constituents of plant extracts possess antimicrobial activities (Ahmed and Beg, 2001). Other researchers have also reported that phenolic and tannin content from plant sources could inhibit various food borne pathogens (Shan et al., 2005). The current study investigated a highly linear correlation between phenolic content and antimicrobial activity of the extracts of $T$. chebula fruits. Same results have been showed between the total tannin content and antimicrobial activity of extracts of $T$. chebula fruits. Shan et al (2007) observed the highly positive correlation between phenolic content and antimicrobial activities of spice and herbs. The present work shows that antimicrobial activity of the extracts of $T$. chebula fruits is closely related to the concentration of phenolic and tannin content of the extracts. The fruit extracts of $T$. chebula in organic solvents possess better antimicrobial activity than sodium benzoate, showing great potential to be developed as a natural preservative to control the spoilage and pathogenic bacteria in fruit juices.

\section{CONCLUSION}

T. chebula is one of the most versatile plants having a wide spectrum of pharmacological and medicinal activities. This versatile medicinal plant is the unique source of various types of compounds having diverse chemical structure. The present study revealed that $T$. chebula possesses promising antimicrobial activity and can serve as an alternative to synthetic antimicrobials. However, further experiments, in vivo studies of these constituents in fruit juices to check the survival of microorganisms and examine its effect on physical, chemical properties of juices.

\section{REFERENCES}

AHMAD, I., BEG, A.Z. 2001. Antimicrobial and phytochemical studies on 45 Indian medicinal plants against multi-drug resistant human pathogens. Journal of Ethnopharmacology, 74, 113-123. http://dx.doi.org/10.1016/s03788741(00)00335-4

AHMAD, I., MEHMOOD, Z., MOHAMMAD, F. 1998. Screening of some Indian medicinal plants for their antimicrobial properties. Journal of Ethnopharmacology, 62,183-193. http://dx.doi.org/10.1016/s0378 8741(98)00055-5

ANEJA, K.R., SHARMA, C., JOSHI, R. 2011. In vitro efficacy of amaltas (Cassia fistula L.) against the pathogens causing otitis externa. Jundishapur Journal of Microbiology, 4 (3), 175-183.

BAG, A., BHATTACHARYYA, S.K., CHATTOPADHYAY, R.R. 2013. The development of Terminalia chebula Retz. (Combretaceae) in clinical research. Asian Pacific Journal of Tropical Biomedicine. 3(3), 244-252. http://dx.doi.org/10.1016/s2221-1691(13)60059-3

BAG, A., BHATTACHARYYA, S.K., PAL, N.K., CHATTOPADHYAY, R.R 2012. In vitro antimicrobial potential of Terminalia chebula fruit extracts against multidrug-resistant uropathogens. Asian Pacific Journal of Tropical Biomedicine, S1883-S1887. http://dx.doi.org/10.1016/s2221-1691(12)60514-0

BEVILACQUA, A., CORBO, M.R., CAMPANIELlO, D., D'AMATO, D., GALLO, M., SPERANZA, B. AND SINIGAGLIA, M. 2011. Shelf life prolongation of fruit juices through essential oils and homogenization: a review. Science against Microbial Pathogens: Communicating Current Research and Technological Advances, 1156-1166.

BONJAR, G.H. 2004. Inhibition of Clotrimazole-resistant Candida albicans by plants used in Iranian folkloric medicine. Fitoterapia, 75 (1), 74-76. http://dx.doi.org/10.1016/i.fitote.2003.08.012

BURT, S. 2004. Essential oils: their antibacterial properties and potential applications in foods: a review. International Journal of Food Microbiology, 94, 223-253. http://dx.doi.org/10.1016/j.ijfoodmicro.2004.03.022

CHANG, C.L., LIN, C.S. 2012. Phytochemical composition, antioxidant activity and neuroprotective effect of Terminalia chebula Retzius extracts. Evidence Based Complementary Alternative $\quad$ Medicine, http://dx.doi.org/10.1155/2012/125247 
CHATTOPADHYAY, R.R., BHATTACHARYYA, S.K. 2007. Terminalia chebula: An update. Pharmacognasy Review, 1, 151-156.

CHIPLEY, J.R. 2005. Sodium benzoate and benzoic acid. In P.M. Davidson, J.N. Sofos and A.L. Branen, Antimicrobials in Food. Taylor and Francis, 11-48.

DAS, K., TIWARI, R.K.S., SHRIVASTAVA, D.K. 2010. Techniques for evaluation of medicinal plant products as antimicrobial agent: Current methods and future trends. Journal of Medicinal Plants Research, 4, 104-111.

DUTTA, B.K., RAHMAN, I., DAS, T.K. 1998. Antifungal activity of Indian plant extracts. Mycoses, 41(11-12), 535-536.

INTERNATIONAL CONFERENCE MICROBIOLOGICALLY SAFE FOODS (ICMSF). 2005. Soft drinks, fruit juices, concentrates and food preserves, In Microorganisms in Foods 6: Microbial ecology of Food Commodity, Kluver Academic Publ.

JUANG, L.J., SHEU, S.J, LIN, T.C. 2004. Determination of hydrolyzable tannins in the fruit of Terminalia chebula by high-performance liquid chromatography and capillary electrophoresis. Journal of Separation Science. 27, 718-724 http://dx.doi.org/10.1002/jssc.200401741

KANNAN, P., RAMADEVI, S.R., HOPPER, W. 2009. Antibacterial activity of Terminalia chebula fruit extract. African Journal of Microbiology Research, 3,180-184.

LAWLOR, K.A., SCHUMAN, J.D., SIMPSON, P.G., P.J. TAORMINA. 2009. Microbiological spoilage of Beverages. In W.H. Sperber, and M.P. Doyle (Eds.), Compendium of the Microbiological Spoilage of Foods and Beverages, Food Microbiology and Food Safety, Springer Sci Busi media, New York, USA.

MEHMOOD, Z., AHMAD, I., MOHAMMAD, F., AHMAD, S. 1999. Indian medicinal plants: A potential source of anticandidal Drug. Pharmaceutical Biology, 37 (3), 237-242.

MOSQUEDA-MELGAR， J., RAYBAUDI-MASSILIA， R.M., MARTIN BELLOSO, O. 2012. Microbiological shelf life and sensory evaluation of fruit juices treated by high intensity electric fields and antimicrobials. Food and Bioproduct Processing, 10, 123-142. http://dx.doi.org/10.1016/i.fbp.2011.03.004

MOSQUEDA-MELGAR, J., RAYBAUDI-MASSILIA, R.M., MARTINBELLOSO, O. 2008. Non-thermal pasteurization of fruit juices by combining high-intensity pulsed electric fields with natural antimicrobials. Innovative Food $\begin{array}{llll}\text { Science } & \text { Emerging } & \text { Technologies, } & \text { 328-340. }\end{array}$ http://dx.doi.org/10.1016/j.ifset.2007.09.003

NCUBE, N.S., AFOLAYAN, A.J., OKOH, A.I. 2008. Assessment techniques of antimicrobial properties of natural compounds of plant origin: current methods and future trends. African Journal of Biotechnology, 7, 1797-1806. 123

NEGI, P.S. 2012. Plant extracts for the control of bacterial growth: Efficacy, stability and safety issues for food application. International Journal of Food Microbiology,

156

$7-17$

http://dx.doi.org/10.1016/j.ijfoodmicro.2012.03.006

RATHINAMOORTHY, R., THILAGAVATHI, G, 2014. Terminalia chebulaReview on pharmacological and biochemical studies. International Journal of Pharmaceutical and Technological Research, 6(1), 97-116.

RAYBAUDI-MASSILIA， R.M， MOSQUEDA-MELGAR， J., SOLIVA FORTUNY, R., MARTIN-BELLOSO. 2009. Control of pathogenic and spoilage microorganisms in fresh cut fruits and fruit juices by traditional and alternative natural antimicrobials. Comprehensive Review in Food Science and Food Safety, 8(3), 157-180. http://dx.doi.org/10.1111/j.1541-4337.2009.00076.x

SHAN, B., CAI, Y.Z., BROOKS, J.D., CORKE, H. 2007. In vitro antibacterial activity of dietary spice and medicinal herb extracts. International Journal of Food Microbiology, 117 http://dx.doi.org/10.1016/j.ijfoodmicro.2007.03.003

SHAN, B., CAI, Y.Z., SUN, M., CORKE, H. 2005. Antioxidant capacity of 26 spice extractrs and characterization of their phenolic constituents. Journal of Agricultural Food $\quad$ Chemistry, 53, 7749-7759. http://dx.doi.org/10.1021/if051513y

SHARMA, C., ANEJA, K.R, KASERA, R., ANEJA, A. 2012. Antimicrobial potential of Terminalia chebula Retz. Fruit extracts against ear pathogens. World Journal of Otorhinolaryngonosy. 2(2), 8-13.

TAJKARIMI, M.M., IBRAHIM, S.A., CLIVER, D.O. 2010. Antimicrobial herb and spice compounds in food. Food Control, 21, 1199-1218 http://dx.doi.org/10.1016/i.foodcont.2010.02.003

TIWARI, B.K., VALDRAMIDI, V.P., O'DONNELL, C.P., MUTHUKUMARAPPAN, K., BOURKE, P., CULLEN, P.J. 2009. Application of natural antimicrobials for food preservation. Journal of Agricultural Food Chemistry, 57, 5987-6000. http://dx.doi.org/10.1021/if900668n

TRIBST, A.A.L., ANA, A.D.S.S., MASSAGUER, P.R.D. 2009. Review: microbiological quality and safety of fruit juices - past, Present and future perspectives. Critical Review in Microbiology, 35(4), 310-339. 